\title{
Sex- and Age-Based Approach to the Study of Interruption in "The Kings of Summer" Movie and "Pretty Little Liars" TV Series: A Case of Same-Sex Teenage Interactions
}

\author{
Eman Riyadh Adeeb ${ }^{1} \&$ Amthal Mohammed Abbas ${ }^{2}$ \\ ${ }^{1}$ College of Education for Human Sciences, University of Diyala, Diyala, Iraq \\ ${ }^{2}$ College of Basic Education, University of Diyala, Diyala, Iraq \\ Correespondence: Eman Riyadh Adeeb, College of Education for Human Sciences, University of Diyala, Diyala, \\ Iraq. E-mail: emmaalqaisi@gmail.com
}

Received: January 2, 2019 Accepted: January 30, 2019 Online Published: February 24, 2019

doi:10.5539/ijel.v9n2p229 URL: https://doi.org/10.5539/ijel.v9n2p229

\begin{abstract}
The study is an attempt to investigate sex and age as crucial factors in the world of interruption. These two factors are investigated theoretically and then practically in two works, "The Kings of Summer" movie and "Pretty Little Liars" TV series. The two works are selected in terms of their compatibility with the core of the study; the characters are teenagers and of the same sex. The study adopts an adapted model to analyze interruption performed by teenagers with special focus on same-sex conversations. The two works' videos were watched and listened to and then their scripts were precisely examined for more reliable results and judgments. The findings demonstrate that teenagers are characterized by their frequent and numerous interruption. Teenage male speakers are more pleased and relaxed to speak and practice interruption with peers (teenage male speakers). Interruption is also familiar in teenage female-female interaction.
\end{abstract}

Keywords: interruption, same-sex conversation, turn-taking

\section{Introduction}

A joke has it that a woman sues her husband for divorce. When the judge asks her why she wants a divorce, she explains that her husband has not spoken to her in two years. The judge then asks the husband, "Why haven't you spoken to your wife in two years?" He replies, "I didn't want to interrupt her."

The study deals with functional interruption. Interruption is a common phenomenon in verbal conversations and it occurs when a speaker violates the other speaker's turn. Generally, sociolinguists consider this phenomenon as a violation of any conversation's rules that govern the relationship between two or group of speakers. Thus, the idea that this study takes its importance from some cases of interruption which can be used by speakers intentionally or (let's say functionally) to fulfill certain purposes. When this is the case, it is believed that such interruption cases are not viewed as violation of the turn-taking rules but they are sort of necessary steps of the conversation. The study covers the concept of "interruption" socio-linguistically and pragmatically and then focuses on the functional usages of the phenomenon.

The study focuses on the two variables, sex and age, in finding out how they affect interruption. Same-sex conversations are focused in order to prove that speakers of the same sex perform interruptions (less or more) than mixed-sex speakers do. The methodology followed is that study adopts an adapted model of Putri's (2014). The two works analyzed are "The Kings of Summer" movie and "Pretty Little Liars" TV series. The reason why these works are selected because their characters are teenagers and of same sex which move hand in hand with subject of the study.

\section{Sex and Age in Communication}

Sex and age, as studies demonstrate, play respectable roles in interruption. The core of the study, as a common stereotype, women tend to speak more frequently than men do. Zimmerman and West (1975, p. 124) conducted a study on university students; they found that men interrupted women in cross-sex conversations. In their later study, in 1978, they came up with that men also interrupt women and control the conversation in the same way as adults control conversations with children. 
Tannen (1990, p. 75), in this respect, states that women speak quite abundantly without delivering a message and this issue motivated people to tell jokes. To agree with, Stubbs (2014, p. 10), in her study on the effect of sex, went to believe that during the last century, sociolinguists were invited to do research on cross-sex communication. She found that a great part of communication falls in the area of seeking "power struggle", or let's say "dominance". Cross-sex interruption has always attracted researchers, that's why this study confines itself to investigate same-sex conversations; male-to-male and female-to-female interaction.

On the other side of the endeavor, age, as a pivotal part, comes to cast its effect on human interaction. Safavi and Zamanian $(2014$, p. 7$)$ prove that young people, including high school and university students, are apt to behave impolitely when communicating with others; they tend to break the rules of interaction. Age, sometimes, might be associated with status which plays an important role in interruption. Aged people often have higher status than young people. Smith-Lovin and Brody $(1989$, p. 424) believe that people of high-status interrupt those people of low-status, old people interrupt young people, etc. Studies on group discussion show that status demonstrates great importance in interaction. Smith-Lovin and Brody proceed to claim that high-status participants are frequently asked their opinion, talk more, receive more positive remarks and may dominate the discussion. Lakoff $(1975$, p. 59) claims that those people who have low status are generally known as being passive. Eakins and Eakins (1978, p. 53) conclude that age and status are substantial elements in the study of interruption; they conducted their study on faculty meetings between male and female officials. They found that men initiated more interruptions than women. Moreover, people, as Eakins and Eakins believe, with high level of status suffered the least number of interruptions.

To note, culture is influential in communication; participants of the same culture share the same beliefs and how-to-act when interacting with each other. Larrue and Trognon (1993, p. 180) hold that thorough interaction depends on shared understanding of behavioral basis. Furthermore, cross-cultural disparity in turn-taking is potential problem in communication.

\section{The Psychological Frame of Interruption}

Why participants interrupt each other might be an incentive for sociolinguists, or sometimes psychologists, to investigate this issue. One may begin to say something but suddenly, someone else interrupts to finish the sentence instead or holding the floor to say another idea without giving an opportunity to let others finish what they want to say. This is frustrating even the first speaker's sentence or thought goes along with the interrupters. Hurd (2016, p. 2) depicts interruption as rudeness, or "something more" (https://drhurd.com/2016/10/16/why-people-interrupt/).

People may interrupt due to certain reasons: linguistic, social or psychological. Linguistically, participants, sometimes, invite other participants to interrupt because they tend to speak slowly and have long pauses. Having passion, some participants try to draw the conversation to the end so fast, or, as Marshal $(2015$, p. 1) addresses it, "they speed up their communication process" while the first speaker tries to include his/her speech with numerous intervals for which Tannen (1980, p. 270) refers as "high considerateness" as having orderly conversation.

A kind of participants try to be supportive by unintentionally interrupting the speakers just to give an idea that they are in line with or understand what is said. Tannen (ibid) calls this style as "high involvement".

In addition, psychologically, shy people give the opportunity to other participants to interrupt or to hold the floor because they either do not have the intent to take part in the discussion or they are shy enough to take their turns. To cope with, Beattie (1983, p. 96) believes that shy people often speak less frequently and for a shorter period of time. Hence, their turn-taking is eventually affected by personality conditions. Beattie proceeds to claim that "Given the centrality of the turn-taking mechanism, individual differences in the style of its operation will undoubtedly influence interpersonal perception".

Further, people may think that they are time-sensitive; they tend to break the rules of communication trying to move to the next urgent issue which attract their attention. They can't wait until the first speaker to finish; interruption is their first choice to do.

Dominance is probably the goal of a kind of interrupters. Participants attempt to dominate other speakers' turn just to prove that they are more powerful and, sometimes, they have long experience and are knowledgeable. Finkelstein (2011, p. 4) believes that bully people (specifically teenagers) think and behave in an aggressive way. They have intent to hurt with the purpose of demeaning and belittling certain people. They, she stresses, interrupt people without discoursal-oriented intention (http://www.marionspeaks.com/_blog/Marions_Communication_Tips/post/WHY_PEOPLE_INTERRUPT/). 
Kunsmann $(2000$, p. 6) states that participants follow different strategies to achieve goal in communication. Interruption is one strategy that participants use due to their relative power that is associated with their social status. The higher level of interruption occurrence is deemed as relatively high social and economic status.

According to the social perspective, some interrupters give themselves the right to do as they believe that interruption is the elixir of a good conversation. Bhargava (2013, p. 3) accounts for interruption stating that the dark part of interruption often falls in the area when one finds him/herself unable to wait to share something. Bhargava suggests that if the participant interrupts with a question, this will give the first speaker a hint to go on, but one can be more active in the conversation by interrupting and adding his/her own point of view (https://www.americanexpress.com/en-us/business/trends-and-insights/articles/why-interrupters-have-the-best-co nversations/).

Interrupting those who used to hold the floor might be socially justified. The interrupter might think that it is time to make the one who holds the floor to feel s/he is dominating and preventing others to deliver their beliefs and ideas. Acts like this is seen as taming and subduing for other to follow the socially agreed-upon traditions and principles of communication.

\section{The Nature of Teenagers' Communication}

Teenagers often attempt to build their esteem as they deal with adults. This draws them to feel with more freedom and most comfortable when they are together with their peers. When this is the case, they share their own language which helps them establish good relationship and confidence with other teenagers.

It is important to distinguish between two type of communication modes: one-to-one and one-to-group of teenagers' communication. The idea is that teenagers, in group interaction, are more motivated to behave in compatible with the group-accepted behavior. Culpeper (1996, p. 352) refers to a type of impoliteness as 'mock' which is heavily applied by young people which is meant to encourage social intimacy and harmony. This type is also focused on by Bernard (1968, p. 782) when referring to as 'inauthentically impolite speech act' to mean that such utterances are typically adhered by laughter or joke. On the other hand, Keinpointer (1997, p. 261) puts another point of view suggesting that it is realized as a kind of cooperative and simulated rudeness. This type, as Culpeper (1996, p. 352) claims, is widespread among young and adolescent people and he associates mock impoliteness with intimacy and banter. Further, he adds, the more intimate people are, more concern they can show to each other. To clarify, in the case of interruption, teenagers are prone to heavily use interruption and overlap in their conversations. The first speaker, the interrupted, is expected, to a large extent, to understand it as sort of joke and fun.

Contrarily, teenagers sometimes may take over another standing. They show tendency to use interruption in response to an interruption occurred on the part of the other speaker; tit-for-tat technique. Generally, this is not linguistically used to achieve certain conversational traits, but it is applied for psychological and sociological issues. This type of interruption, in most cases, involves critical and serious planning by one speaker to offend the other (Rudanko, 2006, p. 829).

\section{Methodology}

The methodology followed in this study involves two phases; the first comprises the instances (sample) of interruption in the two works, "The Kings of Summer" movie and "Pretty Little Liars" TV Series. These two works were selected to be analyzed practically to investigate the use of interruption by the two work's teens. The second focuses on the analysis of the two variables, sex and age, in the selected instances of the works according to the model of the study.

\subsection{The Model}

The model adopted in this study is Putri's (2014) which is sketched as follows: 


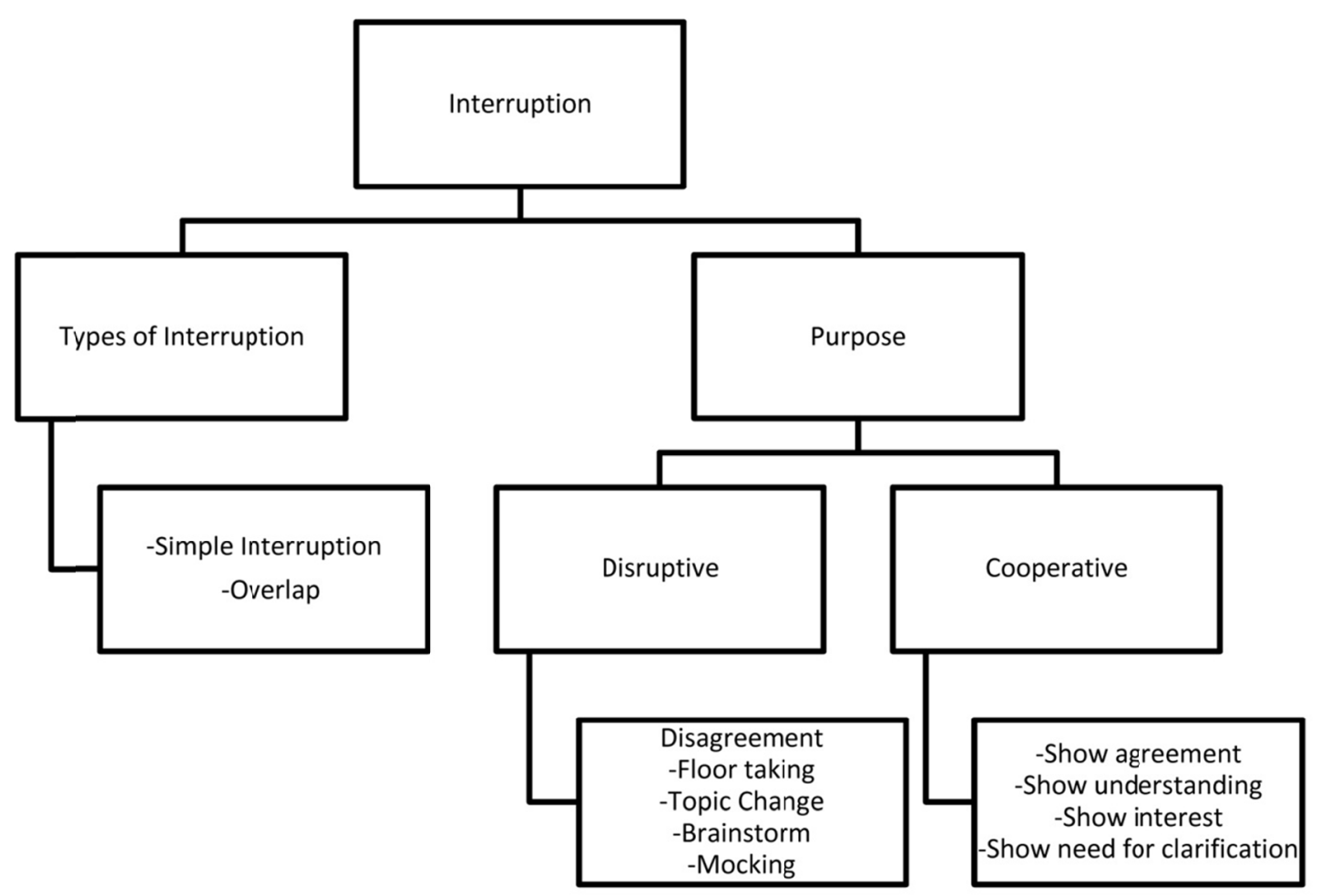

Figure 1. Putri's adapted model (2014)

The model divides interruption into purpose and type of interruption. Purpose, as is known, is divided into cooperative and disruptive. The model confines itself to include only two types of interruption, simple and overlap.

\subsection{Data Collection}

The data of the present study comprise all the interruptions incurred in the form of dialogue and performed by the three male teenage characters with each other and with adult characters in "The Kings of Summer" movie and by the four female teenage characters in "Pretty Little Liars" TV series with each other and with adult characters, male and female. The series covered by the process of analysis include season 1 episodes 1, 2, 3, 4, and 5 which were taken from scripts and videos of the two works.

According to the nature of the present study, one of the procedures followed in qualitative research to collect data is visual analysis; it includes two-fold way. The first is watching and listening to the videos and then, the second, reading the script for reaching accurate judgment regarding the type or the purpose behind interruption.

\subsection{Data Analysis}

Interruptions are analyzed within the framework of Putri's model (2014) which covers the purpose and the types of interruption. As mentioned earlier, the purpose of each interruption is analyzed in terms of cooperative and disruptive ones. According to the purpose, one can decide whether or not the interrupter seeks to hurt the interrupted.

The process of analysis covers a variety of conversations; mixed-gender, male-to-male, male-to-female, adult-to-teenage, teenage-to-teenage and adult-to-adult conversations. This procedure is followed just to accurately find out how sex and age affect the number and purpose of interruption. It would be precise and adequate enough to compare different and varied circumstances regarding different sex and age.

In reference to "The Kings of Summer" movie, the number of characters is 10 tabulated as follows:

Table 1. Number of Characters included in the process of analysis in "The Kings of Summer" movie

\begin{tabular}{lllll}
\hline Sex and Age & Male Teen & Female Teen & Male Adult & Female Adult \\
\hline No. & 3 & 1 & 3 & 3 \\
\hline
\end{tabular}


The number of conversations surveyed according to the participants is distributed as follows:

Table 2. Distribution of conversation number according to sex and age in "The Kings of Summer" movie

\begin{tabular}{lllllll}
\hline Sex & Male-Male & Female-Male & Male-Male & Female-Male & Male-Male & Female-Female \\
Age & Teen & Teen & Adult & Adult & Teen-Adult & Teen-Adult \\
No. & 23 & 3 & 1 & 1 & 6 & 2 \\
\hline
\end{tabular}

Regarding "Pretty Little Liars" TV series, the number of characters is 15 tabulated in the following table:

Table 3. Number of Characters included in the process of analysis in "Pretty Little Liars" TV series

\begin{tabular}{lllll}
\hline Sex and Age & Male Teen & Female Teen & Male Adult & Female Adult \\
\hline No. & 1 & 8 & 3 & 3 \\
\hline
\end{tabular}

Conversations investigated are distributed in the following table:

Table 4. Distribution of conversation number according to sex and age in "Pretty Little Liars" TV series

\begin{tabular}{lllllll}
\hline Sex & Female-Female & Female-Male & Male-Male & Female-Male & Male-Male & Female-Female \\
Age & Teen & Teen & Adult & Adult & Teen-Adult & Teen-Adult \\
No. & 17 & 3 & 3 & 3 & 2 & 3 \\
\hline
\end{tabular}

\subsection{Analysis and Discussion}

The process of analysis is conducted for the purpose of finding out the effectiveness of sex and age on interruption. After applying the model of the study, all conversations were processed twice by the two researchers separately to assure validity and reliability. Each researcher recorded the data in separate record and then both data were compared and examined closely. Some controversial matters regarding the purpose and/or type of interruption were resolved collaboratively just to reach crucial judgment. Further, the data of both researchers were processed and recorded as one final record.

Most importantly, the reason why the two works were selected to analyze in this study is that both address the world of teenagers. The starring characters in both works are teenagers. That's why most conversations are performed by the them. Need to say, not all conversations are included in the process of analysis, but only those which imply interruption of any kind and way.

Table 5. Frequency and percentage of interruption occurrence in "The Kings of Summer" movie

\begin{tabular}{|c|c|c|c|c|c|c|c|c|c|c|}
\hline \multirow{3}{*}{$\begin{array}{l}\text { Conversation } \\
\text { Participants }\end{array}$} & \multicolumn{9}{|c|}{ Purpose of Interruption } & \multirow[t]{3}{*}{ Total } \\
\hline & \multicolumn{5}{|c|}{ Disruptive } & \multicolumn{4}{|c|}{ Cooperative } & \\
\hline & 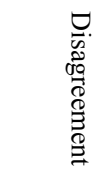 & 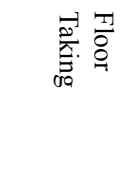 & 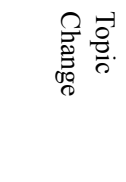 & 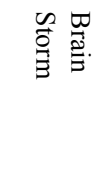 & 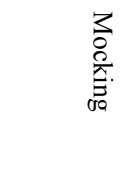 & 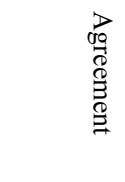 & 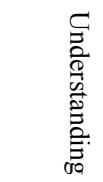 & 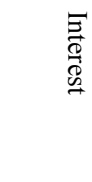 & 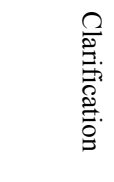 & \\
\hline Male-Male Teen & 6 & 3 & 2 & - & 3 & 2 & 1 & 1 & 1 & $\begin{array}{l}19 \\
65.51 \%\end{array}$ \\
\hline $\begin{array}{l}\text { Female-Male } \\
\text { Teen }\end{array}$ & - & - & 1 & - & - & 1 & - & - & 1 & $\begin{array}{l}3 \\
10.34 \%\end{array}$ \\
\hline $\begin{array}{l}\text { Male-Male } \\
\text { Adult }\end{array}$ & - & - & - & - & - & 1 & - & - & - & $\begin{array}{l}1 \\
3.44 \%\end{array}$ \\
\hline $\begin{array}{l}\text { Female-Male } \\
\text { Adult }\end{array}$ & - & - & - & - & - & - & - & 1 & - & $\begin{array}{l}1 \\
3.44 \%\end{array}$ \\
\hline $\begin{array}{l}\text { Male-Male } \\
\text { Teen-Adult }\end{array}$ & 2 & - & - & 1 & - & - & - & - & - & $\begin{array}{l}3 \\
10.34 \%\end{array}$ \\
\hline $\begin{array}{l}\text { Female-Female } \\
\text { Teen-Adult }\end{array}$ & 1 & - & - & - & - & - & - & & 1 & $\begin{array}{l}2 \\
6.89 \%\end{array}$ \\
\hline Total & $\begin{array}{l}9 \\
31.03 \%\end{array}$ & $\begin{array}{l}3 \\
10.34 \%\end{array}$ & $\begin{array}{l}3 \\
10.34 \%\end{array}$ & $\begin{array}{l}1 \\
3.44 \%\end{array}$ & $\begin{array}{l}3 \\
10.34 \%\end{array}$ & $\begin{array}{l}4 \\
13.79 \%\end{array}$ & $\begin{array}{l}1 \\
3.44 \%\end{array}$ & $\begin{array}{l}2 \\
6.89 \%\end{array}$ & $\begin{array}{l}3 \\
10.34 \%\end{array}$ & 29 \\
\hline
\end{tabular}


Table 6. Frequency and percentage of occurrence of interruption in "Pretty Little Liars" TV Series

\begin{tabular}{lllllllllll}
\hline Conversation \\
Participants
\end{tabular}

The application of the model reveals that teenagers' conversations prevail in the two tables above. It has been found out that $65.51 \%$ of the total interruptions are performed by male-male participants in "The Kings of Summer" movie and $54.83 \%$ by female-female in "Pretty Little Liars" TV series. This shows that the world of teenagers is familiar with the concept of interruption. Teenagers tend to interrupt their addressers for many reasons, amongst is, as the table brings to light, disagreeing with their co-participants to demonstrate their superiority and power. Disagreement represents $29.03 \%$ of the total $65.51 \%$ conducted by male-male participants in the movie while $31.03 \%$ of the total 54.83 in the TV series are conducted by female-female participants. On the other hand, mocking, is demonstrated in $10.34 \%$ of the total interruptions $65.51 \%$ by male participants as compared by female-female ratio 3.22 which proves that teenage male participants frequently attempt to use interruption for mocking-directed reasons rather than teenage female participants.

Floor taking and topic change are used similarly by male or female participants. The percentage reached 10.34 for/by both. Teenage interaction is characterized by disruptive not cooperative interruption. The age stage imposes the impolitely-oriented behavior on the teenagers as they have the activity and power. Disruptive purpose of interruption makes a total of 14 times out of 19 while the cooperative purpose reached 5 time out of 19 of male-male/female-female (same-sex) conversations in "The Kings of Summer" movie. The disruptive/cooperative paradox, in "Pretty Little Liars" TV series makes a ratio of 13/4 out of 17 respectively for the same-sex conversations. This proves that age has a stronger effect, on the account of sex, on the use of interruption in general or disruptive in particular. Very slight difference can be pointed out regarding the difference between male and female use of interruption. Both male and female participants used interruption to fulfill the same purpose; they used the same kinds of disruptive/cooperative purpose with almost converging number of occurrences.

The tables further show that teenage participants used disruptive interruption not only with their counterparts but also with adult participants as well. They use the same way of speaking by virtue of the age period they pass along. The Psychological pressure they yield to make them unaware of the principles and traditions of conversation. Sex and age of the co-participants makes no difference and gives the same consequence.

It has been noticed that teenage male speakers' conversations are void of restrictions and, eventually, they find it more preferable to interact with same-sex co-participants on the account of mixed sex. In "The Kings of Summer" movie, the leading characters are three teenage boys and one girl who favored to live together in the forest to have their own way of life. Their conversations lack the turn-taking hierarchy followed by the adult. In the course of conversations, the boys used to speak differently between each other as compared with the girl (Kelly).

\section{Conclusions}

It can be concluded that interruption is used to attain certain purposes. Disruptive interruption seems to be 
dominating in the teenage interaction rather than cooperative one. This consequence can be ascribed to the psychological and social background of teenage speakers. The findings of application of the model reveal that male-male/female-female (same-sex) conversations can be characterized by numerous disruptive interruptions as compared to mixed-sex ones. The three purposes attained by teenage male or female characters are disagreement, floor taking and topic change. According to table, disagreement occurred more than any other kind of the purposes. This shows that the way of teenagers' thinking is definitely different from the adult's thinking. Contrarily, brainstorming has the lowest ratio of occurrence.

As regard the cooperative interruption, agreement has the highest ratio over understanding, interest and clarification which have equal ratio of occurrence.

The findings also manifest that adult-adult conversation, regardless sex, is almost interruption free due to certain reasons like status and age. While teen-adult conversation is realized to have interruption of low ratio of occurrence.

Since the characters of the movie are so familiar to each other because they live together in a house in the forest, this motivates them to break the rules and have more interruptions than other conversational setting like work place or strangers. Moreover, the TV series' characters used to spend the school and leisure time together which, in turn, gives them the tendency to interrupt each other on the account of other people. Overlaps and interruptions, in this case, occur frequently because such people (friends) know each other very well and can guess what they want to say or have the right to add something to the conversation.

The teenage characters are motivated to interrupt because they seemingly lack patience to wait for the other co-participant to finish his/her turn. This feature is noticeable in teen-teen or teen-adult conversations.

The bad son-father relationship and the case of anger due to the bad behaviors of the sons drive fathers to interrupt their sons' unconvinced by the justifications given by the sons.

\section{References}

American movie The Kings of Summer. (2013).

American TV series Pretty Little Liars. Season I episode 1, 2, 3, 4 and 5. (2010).

Beattie, G. (1983). Talk: An analysis of speech and non-verbal behavior in conversation. Milton Keynes: Open University Press.

Bernard, J. (1968). The Same Sex. Englewood Cliffs, N.J.: Prentice-Hall.

Bhargava, R. (2013). Interrupting People: The Key to Better Conversations. Retrieved from https://www.americanexpress.com/en-us/business/trends-and-insights/articles/why-interrupters-have-the-be st-conversations/

Culpeper, J. (1996). Towards an anatomy of impoliteness. Journal of Pragmatics, 25, 349-367. https://doi.org/10.1016/0378-2166(95)00014-3

Eakins, B., \& Eakins, G. (1976). Verbal Turn-Taking and Exchanges in Faculty Dialogue. In L. D. Betty \& C. Isabel (Eds.), The Sociology of the Languages of American Women (pp. 53-62). San Antonio, TX: Trinity University Press.

Eckert, P., \& McConnell-Ginet, S. (2013). Language and Gender. Cambridge: Cambridge University Press. https://doi.org/10.1017/CBO9781139245883

Finkelstein, M. G. (2011). why people interrupt. Retrieved from http://www.marionspeaks.com/_blog/Marions_Communication_Tips/post/WHY_PEOPLE_INTERRUPT/

Furo, H. (2001). Turn-Taking in English and Japanese: Projectability in Grammar, Intonation and Semantics. New York: Routledge.

Hurd, M. (2016). Why People Interrupt. Retrieved from https://drhurd.com/2016/10/16/why-people-interrupt/

James, D., \& Clarke, S. (1993). Women, Men, and Interruptions: A Critical Review. In T. Deborah (Ed.), Gender and Conversational Interaction (pp. 231-280). New York: Oxford University Press, Inc.

Kienpointer, M. (1997). Varieties of rudeness: Types and functions impolite utterances. Functions of Language, 4(2), 251-287.

Kunsmann, P. (2013). Gender, Status and Power in Discourse Behavior of Men and Women. Retrieved from http://www.linguistik online.com/1_00/kunsmann.htm 
Lakoff, R. T. (1975). Language and woman's place. NY: Harper \& Row.

Larrue, J., \& Trognon, A. (1993). Organization of turn-taking and mechanisms for turn-taking repairs in a chaired meeting. Journal of Pragmatics, 19, 177-196. https://doi.org/10.1016/0378-2166(93)90087-6

Leech, G. (1983). Principles of pragmatics. London: Longman.

McCarthy, M. (1998). Spoken Language and Applied Linguistics. Cambridge: Cambridge University Press.

Pschaid, P. (1993). Language and Power in the Office. Tubingen: Gunter Narr Verlag.

Putri, A. L. (2014). Sociopragmatic Analysis on Interruptions Performed by the Male Characters in New Girl: Season 2 TV Series. Yogyakarta: Yogyakarta State University.

Rudanko, J. (2006). Aggravated Impoliteness and two types of speaker intention in an episode in Shakespeare's Timon of Athens. Journal of Pragmatics, 38, 829-841. https://doi.org/10.1016/j.pragma.2005.11.006

Sacks, H., Schegloff, E., \& Jefferson, G. (1974). A Simple Systematics for Organization of Tum-Taking for Conversation. Language, 50, 696-735. https://doi.org/10.1353/lan.1974.0010

Safavi, M., \& Zamanian, M. (2014). Investigating the Effect of Gender, Age, Education, and Status on Distribution of Politeness Strategies in Persian Requestive Speech Acts. IJLLALW, 7(2), 127-135.

Smith-Lovin, L., \& Brody, C. (1989). Interruptions in Group Discussions: The Effects of Gender and Group Composition. American Sociological Review, 54, 424-435.

Stubbs, K. R. (2014). The Effects of Gender on Interruption among Peers. Undergraduate Honors Theses. Paper 195. Retrieved from https://dc.etsu.edu/honors/195

Tanaka, L. (2004). Gender, Language, Culture: A study of Japanese Television Interview Discourse. Amsterdam: John Benjamins Publishing Company. https://doi.org/10.1075/slcs.69

Tannen, D. (1980). Toward a Theory of Conversational Style: The Machine-Gun Question. Sociolinguistics Working Paper, 73. Austin, TX: Southwest Educational Development Laboratory.

Tannen, D. (1983). When Is an Overlap Not an Interruption? One Component of Conversational Style. In J. D. P. Robert, F. William \& W. Alfred (Eds.), The First Delaware Symposium on Language Studies (vol. 4, pp. 119-129). Newark: University of Delaware Press.

Tannen, D. (1990). Gender Differences in Topical Coherence: Creating Involvement in Best Friends' Talk (pp. 73-90). Discourse Processes.

Yang, L. (1996). Interruption and Intonation. Department of Linguistics, Georgetown University, Washington D.C.

Zhao, X., \& Gantz, W. (2003). Disruption and Cooperative Interruption in Prime-Time Television Fiction: The Role of Gender, Status and Topic. Journal of Communication, 347-362. https://doi.org/10.1111/j.1460-2466.2003.tb02595.x

Zimmerman, D. H., \& West, C. (1975). Sex Roles, Interruptions and Silences in Conversations. In T. Barrie \& H. Nancy (Eds.), Language and Sex: Difference and Dominance (vol. 4, pp. 105-123). Rowley, MA: Newbury House.

\section{Copyrights}

Copyright for this article is retained by the author, with first publication rights granted to the journal.

This is an open-access article distributed under the terms and conditions of the Creative Commons Attribution license (http://creativecommons.org/licenses/by/4.0/). 